\title{
Low level laser therapy for reducing pain in rheumatoid arthritis and osteoarthritis: a systematic review
}

\author{
Terapia Laser de Baixa Intensidade para a redução da dor em \\ artrite reumatoide e osteoatrite: uma revisão sistemática
}

Terapia con Láser de baja intensidad para reducir el dolor en la artritis reumatoide y la osteoartritis: una revisión sistemática

\author{
Renan Fangel@ ${ }^{[a, b]}$ Leticia Meda Vendrusculo-Fangel $\oplus^{[b]}$, \\ Cleandro Pires de Albuquerque $\mathbb{C}^{[c]}$, Nivaldo Antônio Parizotto $\mathbb{C}^{[\mathrm{d}]}$, \\ Clarissa Cardoso dos Santos C. Paz ${ }^{[b]}$, João Paulo Chieregato Matheus $₫[b] *$
}

[a] Centro Universitário EuroAmericano (Unieuro), Brasília, DF, Brazil

[b] Universidade de Brasília (UnB), Brasília, DF, Brazil

${ }^{[c]}$ Hospital Universitário, Universidade de Brasília (HUB/UnB), Brasília, DF, Brazil

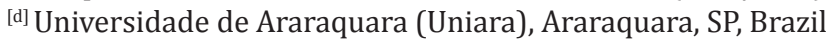

\section{Abstract}

Introduction: Treatments for rheumatoid arthritis (RA) and osteoarthritis (OA) can reduce, modulate inflammation, and reduce deformities. Low-Level Laser Therapy is a biomodulator and may aid in the clinical picture of these conditions. Objective: To analyze the parameters most frequently used to determine the responses of patients with RA and OA in controlled and uncontrolled clinical trials. Method: This is a systematic review with search of articles in English, Portuguese and Spanish in PUBMED, SCOPUS, LILACS

\footnotetext{
* RF: Doctoral Student, e-mail: renanfangel@yahoo.com.br LMVF: PhD, e-mail: leticiamvfangel@unb.br CPA: Doctoral Student, e-mail: cleandropires@hotmail.com NAP: PhD, e-mail: naparizotto@uniara.com.br CCSCP: PhD, e-mail: clarissacardoso@yahoo.com.br JPCM: PhD, e-mail: jpcmatheus@unb.br
} 
and Web of SCIENCE, of articles published between 2006 and 2018. MeSH terms were used. Inclusion criteria: evaluation of LLLT in the evaluations, evaluation and evaluation of the period, controlled and uncontrolled clinical trials, full publications. The base date of the energy dosimetry and the analysis of mean, median and mode of energy per point and energy per treatment. Results: Three articles on RA and 16 on OA were included in this study. Regarding dosimetry, it was one of the most recent of the pain, being this one with a greater energy dose. In OA, most of the articles presented are of importance, with variability in the dosage applied. Conclusion: There are several reports for patient studies purposes, mainly with doses of $6 \mathrm{~J}$ per point and $48 \mathrm{~J}$. In the joints affected with $\mathrm{OA}$ and $\mathrm{AR}$, it would be important to publish more scientific articles with better methodological quality and description of dosimetry.

Keywords: Low-level light therapy. Dosimetry. Rheumatoid Arthritis. Osteoarthritis. Pain.

\section{Resumo}

Introdução: Os tratamentos para artrite reumatoide (AR) e osteoartrite (OA) devem diminuir dor, modular inflamação e diminuir deformidades. O LLLT é um biomodulador e pode auxiliar no quadro clínico destas. objetivo: Analisar os parâmetros mais comumente utilizados para a diminuição das respostas de dor em pacientes com AR e OA em ensaios clínicos controlados e não controlados. Método: Trata-se de uma revisão sistemática com busca de artigos em inglês, português e espanhol na: PUBMED, SCOPUS, LILACS e Web of SCIENCE, entre 2006 a 2018. Foram utilizados os descritores MESH. Critérios de inclusão: avaliação da eficácia do LLLT nestas populações, verificação da dor antes e depois do tratamento, ensaios clínicos controlados e não controlados, publicados integralmente. Foi realizado o cálculo da dosimetria do laser e análise de média, mediana e moda da energia por ponto e energia por tratamento. Resultados: Incluídos neste estudo 3 artigos de AR e 16 de OA. Em relação à dosimetria, apenas um AR apresentou redução da dor, sendo este com a maior dose de energia. Já na OA, a maioria dos artigos apresentou diminuição da dor, e com variabilidade na dosagem aplicada. Alguns tiveram poucos parâmetros apresentados, tornando impossível calcular a dosimetria. Conclusão: há evidências científicas para reduzir a dor relatada em pacientes com $O A$ de joelho, principalmente com doses de $6 \mathrm{~J} \mathrm{por} \mathrm{ponto}$ e $48 \mathrm{~J}$ aplicadas no tratamento diário. Para as outras articulações afetadas com OA e AR, seria importante a publicação de mais artigos científicos com melhor qualidade metodológica e descrição da dosimetria.

Palavras-chave: Terapia com Luz de Baixa Intensidade. Dosimetria. Artrite Reumatoide. Osteoartrite. Dor.

\section{Resumen}

Introducción: Los tratamientos para la artritis reumatoide (AR) y la osteoartritis (OA) pueden reducirse, modular, encender y disminuir las deformidades. El LLLT es un biomodulador y puede auxiliar en el cuadro clínico de éstas. objetivo: Analizar los parámetros más frecuentemente utilizados para determinar las respuestas de pacientes con AR y OA en ensayos clínicos controlados y no controlados. Método: Se trata de una revisión sistemática y la búsqueda de artículos en Inglés, portugués y español en: PubMed, SCOPUS, se utilizaron LILACS y Web of Science, entre 2006 y 2018. Los descriptores de malla. Criterios de inclusión: evaluación de la LLLT en las evaluaciones, evaluación y evaluación del período, ensayos clínicos controlados y no controlados, íntegramente. La fecha base de la dosimetría de energía y el análisis de media, media y moda de la energía por punto y energía por tratamiento. Resultados: Incluido en este estudio 3 artículos de AR y 16 de OA. En cuanto a la dosimetría, fue uno de los más recientes del dolor, siendo éste con una dosis mayor de energía. En la OA, la mayoría de los artículos presentados son de importancia, con la variabilidad en la dosificación aplicada. Se han tenido pocos pocos parámetros parámetros parámetros presentados presentados. Conclusión: hay una serie de informes para fines de estudios con pacientes, principalmente con dosis de $6 \mathrm{~J}$ por punto y $48 \mathrm{~J}$. Las articulaciones afectadas con OA y AR, sería importante la publicación de más artículos científicos con mejor calidad metodológica y descripción de dosimetría.

Palabras clave: Terapia con Luz de Baja Intensidad. Dosimetría. Artritis Reumatoide. Osteoartritis. Dolor. 


\section{Introduction}

Joint pain may be associated with inflammatory $[1,2]$, traumatic or degenerative processes of articular structures $[1,3,4]$. Osteoarthritis (OA) [1] and Rheumatoid Arthritis (RA) [2] are among the most prevalent diseases associated to joint pain.

Rheumatoid Arthritis prevalence ranges from $0.8 \%$ to $2 \%$ of the world population, with a higher occurrence among people between 35-65 years [5, 6]. Regarding $\mathrm{OA}$, it is estimated a prevalence of 27 million people in the adult population of the United States [7]. In Brazil, Senna et al. [8] reported a 4.14\% prevalence in the Brazilian population in 2004.

RA and OA patients have chronic inflammatory process, pain, and functional and biomechanical alterations, which may favor the occurrence of joint injuries. These joint injuries associated with the progression of the disease can increase the degenerative process of the joints, promoting greater structural changes on them, which favors more movement and activity changes [9]. These manifestations alter the accomplishment of the daily living and labor activities, being related to social aspects and daily life, facts that directly impact on the quality of life of the subjects, impairing their psychosocial aspects $[10,11]$.

The treatment for RA and OA should aim to decrease pain, modulate the inflammatory process, decrease deformities, and improve functional capacity and quality of life [12-14]. Low-level laser therapy (LLLT) shows promising therapeutic features in the management of joint inflammation [15]. LLLT may decrease pain $[15,16]$, lower Tumor Necrosis Factor alpha (TNF- $\alpha)[17,18]$, modulate the inflammatory process [18-20], and improve body function $[16,21]$.

The efficacy of LLLT is presumably associated with the parameters used in its application. These parameters have changed with the evolution of the technique, which might dictate the success or failure of laser biomodulation [22-24]. The available information in this regard is controversial since there is favorable data on one hand $[19,21,25]$ and negative results on the other [26-28].

There are several parameters relevant to LLLT usage such as wavelength, power, applied energy and time of application. In daily practice, the clinical physical therapist may face difficulties in choosing the best settings, and some equipment may not provide all the parameters referenced in the scientific literature. Therefore, standardizing a set of parameters that could be chosen with some flexibility would facilitate narrowing the gap between theory and its application in practice.

Currently, two of the most used reference LLLT parameters are the energy applied per point and the energy applied per treatment session.

These factors allow the correct energy to be applied at tissue regardless of output area in laser equipment, while these parameters depend on power and time of application. Therefore, even in different equipment, we can adapt application to fulfill the energy per point and treatment parameters such as the ones by the World Association for Laser Therapy. Energy density parameters widely used as base create different stimulations on tissue, according to the beam output area if they are not adequate reference treatment parameters, and yet there are large differences in the output areas of commercially produced lasers [22-24].

This study sought to conduct a systematic review of the clinical studies that used LLLT for the treatment of RA and OA, to compare the applied energies and, thus establish the best parameters of use by type of joint, since data from the use of LLLT must be better evaluated in a systematic review based on clinical practice and benefiting patients. Currently there are few pieces of data in the literature. The objective was to answer the following research question: "What is the best dosimetry considering the energy parameters of LLLT in individuals with $R A$ and $O A$ in relation to the pain decrease report, considering controlled and uncontrolled clinical trials?".

\section{Method}

Articles suiting the inclusion criteria were searched in PUBMED, SCOPUS, LILACS and WEB OF SCIENCE databases. The search period was from August to September 2018. No article from sources other than these databases was included. For the construction of this review, the PRISMA recommendation (Preferred Reporting Items for Systematic Reviews and MetaAnalyses) was followed [29].

The search focused on articles published between January 2006 and August 2018, in English, Spanish and Portuguese. The searches directed to RA and OA were conducted separately. The descriptors were selected according to their corresponding MeSH term. The chosen descriptors were "Low-Level Light Therapy", "Laser Therapy", "Rheumatoid Arthritis", "Osteoarthritis", and "Pain", which were combined in the following search strategies: 
1) "Low-Level Light Therapy" OR "Laser Therapy" AND "Rheumatoid Arthritis" AND "Pain"

2) "Low-Level Light Therapy" OR "Laser Therapy" AND "Osteoarthritis" AND "Pain"

Identified articles were selected and assessed for eligibility by reading the titles and abstracts and, if necessary, read in full. Included articles were fully read and assessed for matching all the inclusion criteria and for not matching any of the exclusion criteria.

Studies would fulfill the inclusion criteria if they (1) assessed the efficacy of LLLT for treatment of RA or $\mathrm{OA},(2)$ evaluated patient-reported pain before and after treatment, (3) were controlled or uncontrolled clinical trials, and (4) were published in full.

Exclusion criteria were defined as follows: (1) studies in which individuals with diseases other than RA and OA were evaluated in the same treatment group, (2) studies that failed to present exclusive results for LLLT when using combined therapeutic resources, (3) case reports, (4) non-clinical studies.

Two evaluators conducted the process of identification, selection, eligibility and inclusion of articles in an independent way. In case of disagreements, a third evaluator would be called in to settle the question.

The steps of identification, selection, eligibility, inclusion, and exclusion with their correspondent number of articles were summarized in a flowchart (Figures 1 and 2). The included articles were assessed for their contents, with special focus on laser parameters and pain evaluation, and graded for the scientific evidence quality.

To calculate and to describe the dosimetry, the following laser parameters were used: power, time of application, laser output area and number of points per treatment. Other parameters could also be calculated from the basic ones, namely: power density, energy density, energy per point and energy per treatment session [30]. The objective was to establish which laser parameters settings had shown efficacy in consistently decreasing patient-reported pain across the studies, with a special focus on the energy applied per point and per treatment session.

Moreover, all articles selected were evaluated by the PEDro Scale to verify the level of methodological quality and reliability of the results of the evidence found.

\section{Results}

In the search for RA, 15 articles were found in PUBMED, 46 articles in the Web of Science, 32 in SCOPUS and one in LILACS, totaling 94 articles. Of these 94 articles, 22 were duplicates, 55 were unrelated with the subject and the type of study, three were written in languages other than English, Spanish and Portuguese, 9 articles did not present pain evaluation - an inclusion criterion of this study -, and two had a combined treatment. Figure 1 presents a visualization of these data.

In the search for OA, 108 articles were found in PUBMED, 167 articles in the Web of Science, 152 articles in SCOPUS and two articles in LILACS, totaling 429 articles. Of these, 152 articles were duplicates, 217 articles were not related to the theme of this study and were not clinical trials, 13 were published in languages other than English, Spanish and Portuguese, and 31 articles associated other forms of treatment with the use of low-level laser therapy an exclusion criterion of this study. In Figure 2 can be visualized this data.

Three articles on rheumatoid arthritis and 16 articles on osteoarthritis were thus included in the study, which are summarized in Tables 1 and 2 . 


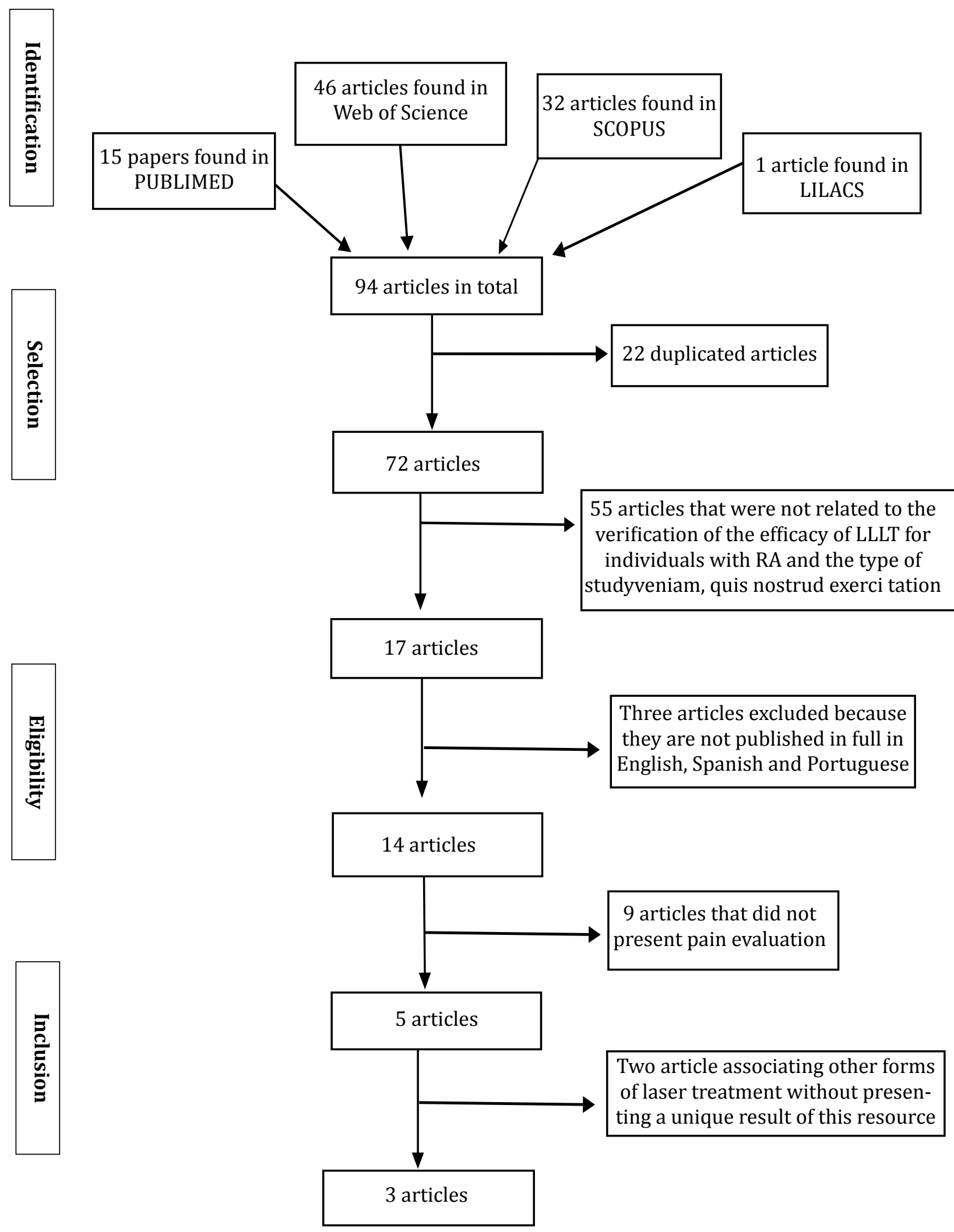

Figure 1 - Flowchart of the selection of articles referring to Rheumatoid Arthritis.

Note: LLLT: Low Intensity Laser Therapy, RA: rheumatoid arthritis. 


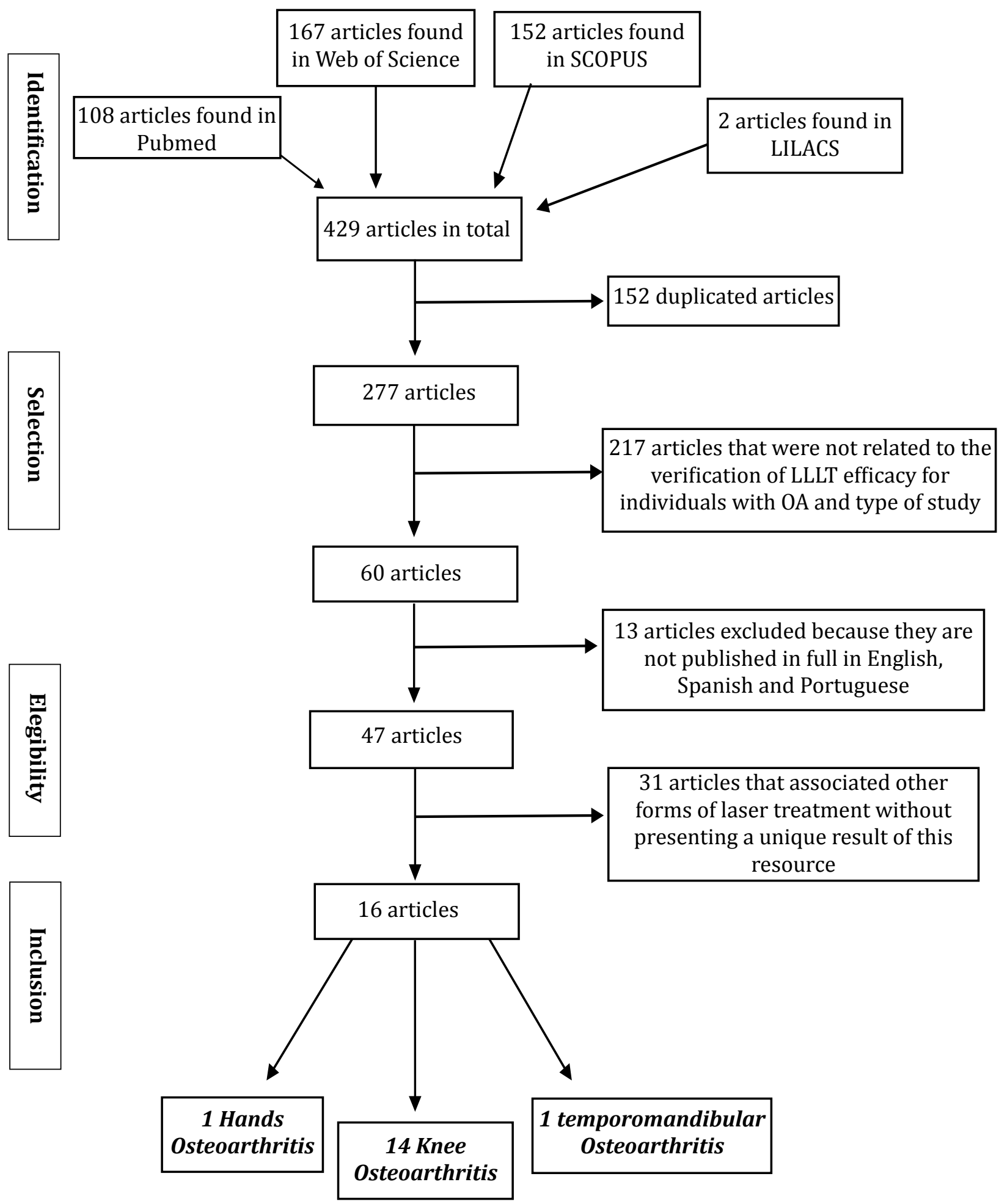

Figure 2 - Flowchart of the selection of the articles referring to Osteoarthritis.

Note: LLLT: Low Intensity Laser Therapy; OA: Osteoarthritis. 


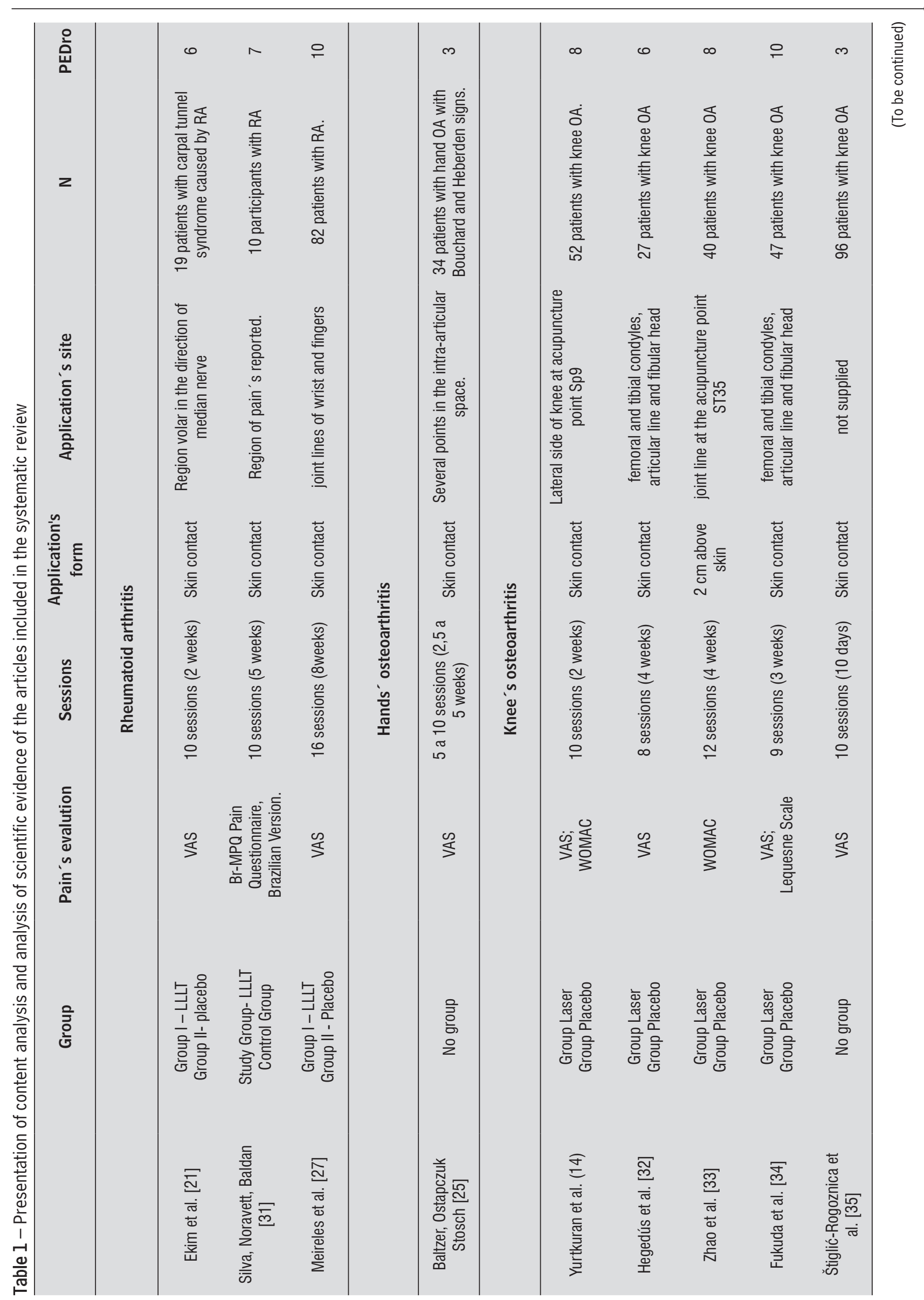




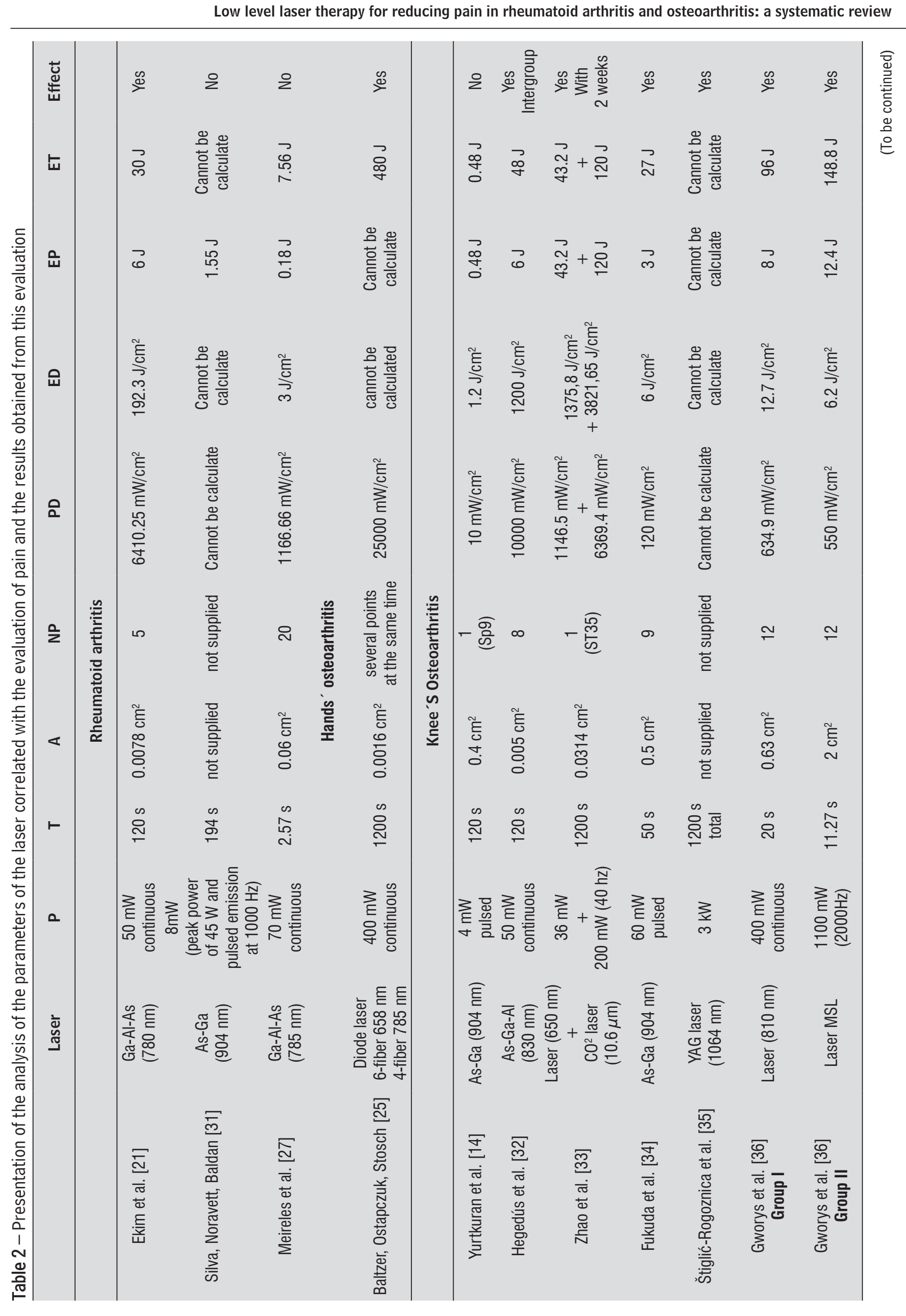


OA studies were separated by anatomic region. One article was found for osteoarthritis of hands and wrists, 14 for knees, and one for the temporomandibular joint.

To determine the best LLLT application parameters in OA and RA the mean, median and mode were calculated. For these calculations, the articles were divided by type of disease, anatomic region and treatment response with or without pain reduction. Table 3 shows the results obtained for knee OA articles with pain reduction after LLLT.

Table 3 - Descriptive analysis of pain-reducing articles after LLLT in knee osteoarthritis

\begin{tabular}{|c|c|c|}
\hline & EP & ET \\
\hline \multicolumn{3}{|c|}{ Knee's osteoarthritis } \\
\hline Mean & $18.94 \mathrm{~J}$ & $218.70 \mathrm{~J}$ \\
\hline Median & $6.3 \mathrm{~J}$ & $48 \mathrm{~J}$ \\
\hline Mode & $6 \mathrm{~J}$ & $48 \mathrm{~J}$ \\
\hline
\end{tabular}

Note: EP: energy per point; ET: energy per treatment; J: joule.

It was impossible to present the results of the other groups due to lack of viable data for these calculations.

\section{Discussion}

We conducted a systematic review of clinical studies that have used LLLT in the treatment of RA and OA. After the removal of duplicates, 72 articles on RA and 277 on OA were found. After the selection considering the established means of inclusion and exclusion criteria, 3 on RA and 16 on OA were obtained. Data for $\mathrm{OA}$ was available in greater number than for RA, in fact, a paucity of information on the efficacy of LLLT for the treatment of RA was evidenced. This difference in the articles found can be explained by the prevalence of the two diseases since OA is more prevalent than RA [42, 43]. In Brazil, OA prevalence rate is $4.14 \%$, whereas $\mathrm{RA}$ rate is $0.46 \%$ [8]

RA is a chronic and progressive systemic rheumatologic disease, mainly affecting joints, also presenting extra-joint manifestations [44, 45]. RA causes synovitis (inflammation of the synovium) with pain, edema and limitation of the amplitude of the movements in the affected joints, which can occur in any part of the body [2]. This condition is characterized by the involvement of small and large joints, in a symmetrical, chronic and limiting way. The chronicity of the disease can cause deformities on bone structures that, associated with the other extra-joint factors, compromise the functional capacity, quality of life and independence of the affected subject $[3,46]$.

Therefore, RA patients need effective treatments to control the disease, decrease the inflammatory process and deformities, increasing function and independence. LLLT could thus be an interesting resource because it presents some evidences in decreasing TNF- $\alpha$ [17] and modulating the inflammatory process $[19,20]$, factors that are involved in the cause of joint deformities [6].

In this study, we found poor evidence supporting that LLLT does not work for the treatment of RA, having patient-reported pain as the main outcome, since only one out of three double-blind randomized studies included in this review showed a positive result $[14,20,31]$. We should note that this sole favorable trial, by Elkim et al. [14], with a small number of subjects ( $\mathrm{n}=19)$, had the lowest PEDro score among them. The largest study $(n=82)$, by Meireles et al. [27], with the highest PEDro score, showed no significant improvement in pain, as assessed by the Visual Analogue Scale (VAS) (Table 1).

Ekim et al. [21] utilized doses of energy per point and per treatment session of $6 \mathrm{~J}$ and $30 \mathrm{~J}$, respectively, much higher than in the other two trials. Silva et al. [31] reported $1.55 \mathrm{~J}$ per point doses (dose per treatment could not be calculated). Meireles et al. [27] used a $0.18 \mathrm{~J}$ per point dose and $7.56 \mathrm{~J}$ per treatment session dose. Energy doses of studies that did not show beneficial results from LLLT are below the recommended values by the World Association for Laser Therapy, which establishes $28 \mathrm{~J}$ as the energy per treatment session [22]. Therefore, it is at least doubtful to infer that LLLT is not beneficial to the treatment of RA. More studies with adequate methodology are clearly needed in this regard.

Regarding 0A, 16 articles were found, which were evaluated by target joint, because while RA presents more systemic characteristics, $\mathrm{OA}$ can be understood as a more localized process. OA is a rheumatic, articular, degenerative and chronic disease that is associated with biomechanical factors, such as joint overload, and biological factors, such as biochemical changes in cartilage and synovial membrane [1]. OA patients may present with pain, edema, ligament laxity, joint stiffness, decreased movement, muscle weakness, slower movement speed, joint instability and deformities. These factors may compromise quality of life and function [33, 47-49]. 
As in RA, OA patients require effective treatments to control the disease, decrease the inflammatory process, and increase function and independence. Thus, LLLT could be an interesting resource since it presents some evidence in decreasing TNF- $\alpha$ and modulating the inflammatory process [14], and, in this case, LLLT can also be considered a potentially effective resource. However, LLLT's potential must be proven via systematic reviews.

Regarding hand and wrist OA, only one article was found, which reported positive results in pain reduction [25]. This study had a low PEDro score of 3 . There was no control group, and the LLLT dosimetry was not adequately described, precluding proper assessment and reproduction of the study methods [25].

Regarding knee OA, 14 articles were included, 12 out of which showed positive results in decreasing patient-reported pain. (Table 1)

We must note that the two studies that found no significant improvement in pain used lower laser doses. Yurtkuran et al. [14] applied $0.48 \mathrm{~J}$ per point and $0.48 \mathrm{~J}$ per treatment session. Hinman et al. [28] did not reported all laser application parameters but indicated that a 0.2 J per point was used, without reporting the number of points. These lower doses could possibly explain their negative results with LLLT application.

Among the studies with positive results, 10 were randomized clinical trials (eight with a double-blind design), and four were uncontrolled studies. Regarding dosimetry, energy per point values ranging from 1.5 J to 163.2 J were applied, with the most used energy being around 6 J (on five studies). Regarding energy per treatment session, values ranged from $12 \mathrm{~J}$ to $2400 \mathrm{~J}$, with the most applied value being $48 \mathrm{~J}$ (on three studies).

These data allows us to conclude that there is evidence in favor of LLLT application for pain reduction in knee OA. Values of $6 \mathrm{~J}$ per point and 48 J per treatment session are advocated since they were most used in studies with positive results; however, the great variation in dosimetry across the studies should be acknowledged (Table 3).

Only one article addressing temporomandibular joint OA was found, which showed no significant improvement in pain from LLLT application [33]. This was a double-blind randomized clinical trial $(\mathrm{n}=20)$, with a PEDro score of 8. The energy per point applied was $6 \mathrm{~J}$ (energy per treatment session could not be calculated from the reported data). Given the small number of participants in this study and the incompleteness of laser parameters, no firm conclusion can be drawn regarding the efficacy of LLLT in the treatment of temporomandibular OA.

The applications sites and forms in RA and $\mathrm{OA}$ were analyzed, and it was verified that almost all studies presented application with skin contact. Only one study [33] applied the laser $2 \mathrm{~cm}$ away from the skin to not generate burns. This same study [33] used the highest energy doses per point and presented an energy loss that cannot be quantified. The application with contact allows greater penetration of the laser [30]. Regarding the application site points, there was great variability but the most common were regions near the articular lines, given that RA mainly affects synovial membranes and $\mathrm{OA}$ articular cartilage.

This systematic review demonstrates the importance of the presence of the basic parameters of the use of LLLT to verify the benefit or not of this technique. For such, it is necessary to unify dosimetrymainly as power -, application time per point and number of points. Jenkins \& Carrol [30] present a standardization possibility for these parameters.

The studies should be compared in relation to their results but also in relation to the dosimetry used, since these dose values may explain the success or failure of the treatment. In this systematic review, the parameters of energy per point and energy per treatment were calculated a priori; when they could not be calculated, the values described in the methods of the original articles were used. There is plenty of confusion between the parameters of energy per point, energy density and energy per treatment, which makes the use of this data unfeasible without proper examination via calculations. Some studies $[25,28,31,35,37,41-43]$ had few parameters of use of the resource, both making it impossible to calculate the dosimetry, and impairing reproducibility, thus compromising its methodological quality.

This study prioritized the use of energy applied per point and treatment as reference for the orientation of the clinical physical therapist. Since there are many LLLT equipment with fixed basic parameters such as laser output area and power values, these values are standardized according to the brand and the type of laser devices available in the consumer market; thus, the clinical physical therapist should have an independent reference value of the type of device used. We must emphasize that the power must promote an adequate depth of the applied energy, and the time must be determined by the power and the energy that one wants to apply. The number of points should be 
chosen according to the area of the joint to standardize the energy across the target regions and consider the energy to be applied by treatment and joint.

Failure to present reliable data for the original articles of the basic laser parameters may generate errors in the calculation of the energy parameters used. Moreover, the studies showed differences in LLLT equipment that may complicate the understanding of the basic usage mechanisms of the technique.

This systematic review emphasizes the importance of providing a clear picture of the basic LLLT parameters such as power, application time per point and number of points, when reporting results on the efficacy of this technique. With these basic parameters, one can calculate the energy per point and per treatment session, which are deemed here to be the most important determinants associated with a clinical response to LLLT.

\section{Conclusion}

Favorable evidence that LLLT can reduce pain in patients with knee OA exists, mainly with doses of $6 \mathrm{~J}$ per point and $48 \mathrm{~J}$ per treatment session. Regarding RA and $\mathrm{OA}$ on other joints, there is a clear need for more studies, with better methodological quality and proper description of the applied dosimetry so any conclusions on the efficacy of this technique can be supported.

\section{Acknowledgements}

The authors are grateful to Universidade de Brasília and the multiprofessional team of rheumatology of the University Hospital of Brasília. This study was part of the doctoral research performed by MS. Renan Fangel in the "Programa de Pós Graduação em Ciências e Tecnologias em Saúde - PPGCTS, FCE, UnB". Thus, we thank the graduate students in physical therapy at UnB and Unieuro who assisted in the other stages of the doctorate.

\section{References}

1. Coimbra IB, Pastor EH, Greve JMD, Puccinelli MLC, Fuller R, Cavalcanti FS, et al. Osteoartrite (artrose): tratamento. Rev Bras Reumatol. 2004;44(6):450-3.

2. Mota LMH, Cruz BA, Brenol CV, Pereira IA, Fronza LSR, Bertolo MB, et al. Consenso da Sociedade Brasileira de Reumatologia 2011 para o diagnóstico e avaliação inicial da artrite reumatoide. Rev Bras Reumatol. 2011;51(3):199-219.
3. Mota LMH, Cruz BA, Brenol CV, Pereira IA, RezendeFronza LS, Bertolo MB, et al. Disability and quality-of-life are not influenced by the prevalence of autoantibodies in early rheumatoid arthritis patients-results of the Brasília Cohort. Rev Bras Reumatol. 2012;52(6):819-29.

4. McInnes IB, O'Dell JR. State-of-the-art: rheumatoid arthritis. Ann Rheum Dis. 2010;69(11):1898-906.

5. Laurindo IMM, Pinheiro GRC, Ximenes AC, Xavier RM, Giorgi RDN, Ciconelli RM, et al. Consenso brasileiro para diagnóstico e tratamento da artrite reumatóide. Rev Bras Reumatol. 2002;42(6):355-61.

6. 6. Rodrigues CRF, Dal Bó S, Teixeira RM. Diagnóstico Precoce da Artrite Reumatoide. Rev Bras Anal Clin. 2005;37(4):201-4.

7. Lawrence RC, Felson DT, Helmick CG, Arnold LM, Choi H, Deyo RA, et al. Estimates of the prevalence of arthritis and other rheumatic conditions in the United States: part II. Arthritis Rheum. 2008;58(1):26-35.

8. Senna ER, Barros AL, Silva EO, Costa IF, Pereira LV, Ciconelli RM, et al. Prevalence of rheumatic diseases in Brazil: a study using the COPCORD approach. J Rheumatol. 2004;31(3):594-7.

9. Stevens M, Paans N, Wagenmakers R, van Beveren J, van RaayJJ, van der Meer K, et al. The influence of overweight/ obesity on patient-perceived physical functioning and health-related quality of life after primary total hip arthroplasty. Obes Surg. 2012;22(4):523-9.

10. Bajuri, MN, Kadir MR, Ramam MM, Kamanul T. Mechanical and functional assessment of the wrist affected by rheumatoid arthritis: a finite element analysis. Med Enginee Phys. 2012;34(9):1294-302.

11. Salaffi F, Carotti M, Gasparini S, Intorcia M, Grassi W. The health-related quality of life in rheumatoid arthritis, ankylosing spondylitis, and psoriatic arthritis: a comparison with a selected sample of healthy people. Health Qual Life Outcomes. 2009;7:25-37.

12. Christie A, Jamtvedt G, Dahm KT, Moe RH, Haavardsholm EA, Hagen KB. Effectiveness of nonpharmacological and nonsurgical interventions for patients with rheumatoid arthritis: an overview of systematic reviews. Phys Ther. 2007;87(12):1697-715. 
13. Ottawa Panel. Ottawa Panel evidence-based clinical practice guidelines for therapeutic exercises in the management of rheumatoid arthritis in adults. Phys Ther. 2004;84(10):934-72.

14. Yurtkuran M, Alp A, Konur S, Özçakir S, Bingol U. Laser acupuncture in knee osteoarthritis: a double-blind, randomized controlled study. Photomed Laser Surg. 2007;25(1):14-20.

15. Ottawa Panel. Ottawa Panel evidence-based clinical practice guidelines for electrotherapy and thermotherapy interventions in the management of rheumatoid arthritis in adults. Phys Ther. 2004;84(11):1016-43

16. Alghadir A, Omar MT, Al-Askar AB, Al-Muteri NK. Effect of low-level laser therapy in patients with chronic knee osteoarthritis: a single-blinded randomized clinical study. Lasers Med Sci. 2014;29(2):749-55.

17. Aimbire F, Albertini R, Pacheco MTT, Castro-FariaNeto HC, Leonardo PS, Iversen VV, et al. Low-level laser therapy induces dose-dependent reduction of TNF alpha levels in acute inflammation. Photomed Laser Surg. 2006;24(1):33-7.

18. El-Kharbotly AM, El-Gendy AA, Mohammed MA, El-Masry MR, Daoud EM, Hassan N, et al. Effect of laser versus acupuncture traditional acupuncture in neck pain of cervical spondylosis. Proceedings Spie. 2014;8932:89320Z.

19. Yamaura M, Yao M, Yaroslavsky I, Cohen R, Smotrich M, Kochevar IE. Low level light effects on inflammatory cytokine production by rheumatoid arthritis synoviocytes. Lasers Surg Med. 2009;41(4):282-90.

20. Alves AC, Carvalho PT, Parente M, Xavier M, Frigo L, Aimbire F, et al. Low-level laser therapy in different stages of rheumatoid arthritis: a histological study. Lasers Med Sci. 2013;28(2):529-36.

21. Ekim A, Armagan O, Tascioglu F, Oner C, Colak M. Effect of low level laser therapy in rheumatoid arthritis patients with carpal tunnel syndrome. Swiss Med Wkly. 2007;137(23-24):347-52.
22. Tunér J, Hode L. Low-level laser therapy for hand arthritis-fact or fiction? Clin Rheumatol. 2010;29(9):1075-6.

23. Meireles SM, Jones A, Natour J. Low-level laser therapy on hands of patients with rheumatoid arthritis. Clin Rheumatol. 2011;30(1):147-8.

24. Jang $H$, Lee H. Meta-analysis of pain relief effects by laser irradiation on joint areas. Photomed Laser Surg. 2012;30(8):405-17.

25. Baltzer AW, Ostapczuk MS, Stosch D. Positive effects of low level laser therapy (LLLT) on Bouchard's and Heberden's osteoarthritis. Lasers Surg Med. 2016;48(5):498-504.

26. Goats GC, Hunter JA, Flett E, Stirling A. Low intensity laser and phototherapy for rheumatoid arthritis. Physiotherapy. 1996;82(5):311-20.

27. Meireles SM, Jones A, Jennings F, Suda AL, Parizotto NA, Natour J. Assessment of the effectiveness of lowlevel laser therapy on the hands of patients with rheumatoid arthritis: a randomized double-blind controlled trial. Clin Rheumatol. 2010;29(5):501-9.

28. Hinman RS, McCrory P, Pirotta M, Relf I, Forbes A, Crossley KM, et al. Acupuncture for chronic knee pain: a randomized clinical trial. Jama. 2014;312(13):1313-22.

29. Moher D, Liberati A, Tetzlaff J, Altman DG; Prisma Group. Preferred reporting items for systematic reviews and meta-analyses: the PRISMA statement. PLoS Med. 2009;6(7):e1000097.

30. Jenkins PA, Carroll JD. How to report low-level laser therapy (LLLT)/photomedicine dose and beam parameters in clinical and laboratory studies. Photomed Laser Surg. 2011;29(12):785-7.

31. Silva DP, Novaretti APOC, Baldan C. Efeito analgésico do laser de baixa intensidade (LILT) na artrite reumatóide aguda. Rev Inst Cienc Saude. 2009;27(1):35-8.

32. Hegedűs B, Viharos L, Gervain M, Gálfi M. The effect of low-level laser in knee osteoarthritis: a double-blind, randomized, placebo-controlled trial. Photomed Laser Surg. 2009;27(4):577-84. 
33. Zhao L, Shen X, Cheng K, Deng H, Ding G, Tan M, et al. Validating a nonacupoint sham control for laser treatment of knee osteoarthritis. Photomed Laser Surg. 2010;28(3):351-6.

34. Fukuda VO, Fukuda TY, Guimarães M, Shiwa S, Lima B del C, Martins RA, et al. Short-term efficacy of low-level laser therapy in patients with knee osteoarthritis: a randomized placebo-controlled, double-blind clinical trial. Rev Bras Ortop. 2011;46(5):526-33.

35. Štiglić-Rogoznica N, Stamenković D, Frlan-Vrgoc L, Avancini-Dobrović V, Vrbanić TS. Analgesic effect of high intensity laser therapy in knee osteoarthritis. Coll Antropol. 2011;35(2):183-5.

36. Gworys K, Gasztych J, Puzder A, Gworys P, Kujawa $J$. Influence of various laser therapy methods on knee joint pain and function in patients with knee osteoarthritis. Ortop Traumatol Rehabil. 2011;14(3):269-77.

37. Kędzierski T, Stańczak K, Gworys K, Gasztych J, Sibiński M, Kujawa J. Comparative evaluation of the direct analgesic efficacy of selected physiotherapeutic methods in subjects with knee joint degenerative disease-preliminary report. Ortop Traumatol Rehabil. 2011;14(6):537-44.

38. Rayegani SM, Bahrami MH, Elyaspour D, Saeidi M, Sanjari H. Therapeutic effects of low level laser therapy (LLLT) in knee osteoarthritis, compared to therapeutic ultrasound. J Lasers Med Sci. 2012;3(2):71-4.

39. Nakamura T, Ebihara S, Ohkuni I, Izukura H, Harada $\mathrm{T}$, Ushigome $\mathrm{N}$, et al. Low Level Laser Therapy for chronic knee joint pain patients. Laser Ther. 2014;23(4):273-7.

40. Soleimanpour H, Gahramani K, Taheri R, Golzari SE, Safari S, Esfanjani RM, et al. The effect of low-level laser therapy on knee osteoarthritis: prospective, descriptive study. Lasers Med Sci. 2014;29(5):1695-700.

41. Nambi G, Kamal W, George J, Manssor, E. Radiological and biochemical effects (CTX-II, MMP-3, 8, and 13) of low-level laser therapy (LLLT) in chronic osteoarthritis in Al-Kharj, Saudi Arabia. Lasers Med Sci. 2017;32(2):297-303.
42. Nazari A, Moezy A, Nejati P, Mazaherinezhad A. Efficacy of high-intensity laser therapy in comparison with conventional physiotherapy and exercise therapy on pain and function of patients with knee osteoarthritis: a randomized controlled trial with 12-week follow up. Lasers Med Sci. 2019;34(3):505-16.

43. Madani AS, Ahrari F, Nasiri F, Abtahi M, Tunér J. Low-level laser therapy for management of TMJ osteoarthritis. Cranio. 2014;32(1):38-44.

44. Alamanos Y, Drosos AA. Epidemiology of adult rheumatoid arthritis. Autoimmun Rev. 2005;4(3):130-6.

45. Dillon CF, Rasch EK, Gu Q Hirsch R. Prevalence of knee osteoarthritis in the United States: arthritis data from the Third National Health and Nutrition Examination Survey 1991-94. J Rheumatol. 2006;33(11):2271-9.

46. Mota LMH, Cruz BA, Brenol CV, Pereira IA, RezendeFronza LS, Bertolo MB, et al. Consenso 2012 da Sociedade Brasileira de Reumatologia para o tratamento da artrite reumatoide. Rev Bras Reumatol. 2012;52(2):135-74.

47. Duarte VS, Santos ML, Rodrigues KA, Ramires JB, Arêas GPT, Borges GF. Exercícios físicos e osteoartrose: uma revisão sistemática. Fisioter Mov. 2013;26(1):193-202.

48. Barduzzi GO, Rocha PR Jr, Souza JC Neto, Aveiro MC. Capacidade funcional de idosos com osteoartrite submetidos a fisioterapia aquática e terrestre. Fisioter Mov. 2013;26(2):349-60.

49. Facci LM, Marquetti R, Coelho KC. Fisioterapia aquática no tratamento da osteoartrite de joelho: série de casos. Fisioter Mov. 2007;20(1):17-27.

Received in 05/24/2018

Recebido em 24/05/2018

Recibido en 24/05/2018

Approved in 04/11/2019

Aprovado em 11/04/2019

Aprobado en 11/04/2019 